\title{
Tourism and energy: classical economics and the oximorum of sustainable tourism
}

\section{Turismo y energía: economía clásica y el oxímoron del turismo sostenible}

\author{
OSORIO-MOLINA, Francisco Manuel†* \\ Universidad de Córdoba, Facultad de Ciencias del Trabajo y Turismo \\ ID $1^{\text {st }}$ Author: Francisco Manuel, Osorio-Molina / ORC ID: 0000-0001-9349-8677
}

DOI: 10.35429/EJM.2020.25.11.12.23

Received July 09, 2020; Accepted December 14, 2020

\begin{abstract}
Tourism activity is one of the most important economic activities globally, but due to its complexity, its study should not be based solely on an economic perspective. A systemic and multidisciplinary vision is necessary to understand and clarify the problems this tourist activity presents. Introducing inevitably, in this systemic vision, the energy variable hitherto hidden, that supports and allows the development of tourism activity in the search for a real sustainability. Since this imposed reality, whose greatest exponent is monetary reductionism, leads us to ignore the resources that really are the essential support of tourism, and ultimately, of any anthropological activity.
\end{abstract}

Energy perspective, Monetary reductionism, Real sustainability

\section{Resumen}

La actividad turística es una de las actividades económicas más importantes a nivel global, pero debido a su complejidad, su estudio no debe sustentarse únicamente a través de una mirada económica, sino que es necesario una visión sistémica y multidisciplinar para comprender y dilucidar las problemáticas que esta actividad turística presenta. Introduciendo inevitablemente, en esta visión sistémica, la variable energética hasta ahora oculta, que soporta y permite el desarrollo de la actividad turística en la búsqueda de una sostenibilidad real y no impostada. Ya que esta realidad impostada, cuyo mayor exponente es el reduccionismo monetario, nos lleva a obviar los recursos que realmente son el soporte esencial del turismo, y en definitiva, de cualquier actividad antropológica.

Variable energética, Reduccionismo monetario, Sostenibilidad real

Citation: OSORIO-MOLINA, Francisco Manuel. Tourism and energy: classical economics and the oximorum of sustainable tourism. ECORFAN Journal-Mexico. 2020. 11-25: 12-23.

\footnotetext{
* Correspondence to Author (E-mail: erebus44356562c@gmail.com)

$\dagger$ Researcher contributing first author.
} 


\section{Introduction}

The tourist activity is one of the most marked activities in the last decades at a global level. So much so, that it is even cataloged as the engine of development and growth of an immense number of Nation-States on the planet (UNWTO, 2016: 2 ). Which cannot surprise us, if we approach its most remarkable economic figures. To highlight, both its contribution to the world gross domestic product, as well as employment and investment at global levels. Being in 2019, this tourist activity, responsible for $10.3 \%$ of the world Gross Domestic Product and setting a new record in terms of the number of jobs dependent on the activity. Number of jobs that managed to reach the not inconsiderable amount of 330 million, which finally translated into $10 \%$ of global employment (UNWTO, 2019: 1). Also presented are direct investment figures that reached 882.4 trillion dollars (OMT, 2019: 7).

Parallel to the increase in the economic importance in the global production of tourism activity, the study of it by the Spanish academic field has also increased (López-Bonilla; Granados-Perea and López-Bonilla), pointing out in recent years years, the high level of systemic complexity that the tourist activity presents in its study, and which implies that the only way to make a correct approach to it is through a global, multidisciplinary and systemic vision that caters to multiple actors, factors and conditioning factors that go from planning to final development and consumption (Jafari 2005). All this, in order to understand, the huge synergies, relationships and interdependencies that originate between the tourist activity and the rest of the anthropological activities that, simultaneously, are generated and fight to dominate the spaces / territories (Cabrerizo 2016; Morell y Membrado-Tena, 2018; Zaar and Pontes da Fonseca 2018), in our current and complex societies; characterized by their multifaceted liquid modernity (Bauman: 2016) and where urban happiness (Muñoz and Martínez 2020) is conspicuous by its absence, as a consequence of more than a decade of stagnant wages and increased inequality (Bizberg, Morayta and Mabire: 2020). But if we do not undertake this task, and only use the myopic glasses that monetary reductionism offers us (Bendodo, Fernández and Sánchez, 2019), we run the risk of overlooking the real value of the natural resources that support the activity itself, such as are the energy flows and the material funds.
Which, although they are the substantial thing in terms of the sustainability of the tourist activity, as happens with any other anthropological activity, monetary blindness, gives it a meager crematistic value (Delgado, Reigada, Soler and Pérez: 2015); as also occurs with work activities that are related to care (López and Medina: 2020) and that are necessary for the development of tourism activity.

So, currently, and from an academic and / or professional point of view, we are approaching the tourist activity attending to a quasi-systemic vision that encompasses multiple edges such as: the economic, the labor, the social, the cultural, the tax, the space and the environment.

But in no case do we attend to the gigantic consumption of fossil energy natural resources necessary as a prerequisite to carry out the activity. Which is somewhat surprising, since if we attend to the very definition of the concept of tourism, regardless of the organ, entity or author to which we go for it, we will find that tourist activity is an anthropological and spatial activity that takes place in a space / concrete territory. Or expressed in another way; Tourism is a human activity that inherently involves a movement from point A (sending territory) to point B (receiving territory). So the impossibility of separating the variable displacement from the concept of tourism itself, is something evident and ultimately fundamental.

This phenomenon translates into the need to maintain an upward consumption of net energy from fossil natural resources, in order to sustain the increasing rate of both tourist activity and its associated and necessary auxiliary activities for the development of the activity. (infrastructures, communications, capital goods, etc.), at the current times of decrease in terms of fossil energy natural resources in which we currently find ourselves, after having exceeded the peak of production of conventional oil by 2006, (IEA 2010 at: 122). Which leads us to ask ourselves questions such as the following:

- Are the forecasts of the World Tourism Organization (UNWTO), consistent with exceeding the figure of 1.8 billion international tourists in 2030, feasible from an energy point of view (UNWTO, 2011: $15)$ ? 
- Can tourism be the engine of growth and development of the vast majority of the Nation-States of the planet (UNWTO, 2016: 2), taking into account the scenario of absolute (biophysical), not relative (economic) energy scarcity, which is Presents us today and that foreseeably, will be more in the next decades?.

- Is there an energy substitute for fossil natural resources that allows us to continue increasing the level of tourist (and economic) production and consumption, globally at constant rates as until now? (Prieto \& Hall, 2012).

These questions, which very possibly, cannot be answered, without observing a few basic concepts of both physics and economics.

\section{Energy}

The Dictionary of the Royal Academy of the Spanish Language defines the term energy as follows:

- $\quad$ Efficacy, power, virtue to act.

- $\quad$ Ability to perform work. It is measured in joules.

Taking into account both definitions, we can check how energy is a force that allows us to do some type of work (perform an action), being able to classify the types of energy that humans can use into endosomatic energy, which is the energy obtained through from food and solar radiation, and that is generated in the human body, and exosomatic, which is that energy produced outside it. But regardless of whether this energy, whether endosomatic or exosomatic, in both cases, attends to unalterable physical concepts that act as biophysical patterns and limits, called the laws of thermodynamics.

The first law of thermodynamics, known as the law of conservation of energy, states that matter and energy cannot be destroyed or created. (Müller 2002: 165). While the second law, also called the law of entropy, stipulates that as long as there are no external sources of energy, entropy always increases.. (Müller: 2002:181).

In keeping with this first law of thermodynamics, economic activity does not create or destroy matter or energy.
What is done through the economic process, is to absorb and expel, matter and energy. Being the difference between what enters the economic process, and what comes out of it, a difference not quantitative, but qualitative. Matter and energy enter the economic process in a state of low entropy and leave it, in a state of high entropy as it follows from the second law, meaning that energy is dispersed and degrades (Van Hauwermeiren 1999: 51).

Throughout history, societies have used different energy sources, attending to multiple variables such as: their technological level, their entropic level or simply attending to their energy needs (the number of individuals of which they were composed and their level of complexity). Thus in forage societies a reduced amount of energy was needed, since they presented a low specialization, and therefore, a meager need when it comes to a social organization to sustain themselves. On the contrary, in an agrarian society, a greater amount of energy is required, as well as a greater specialization and a more complex social organization. (Fernández-Durán and GonzálesReves 2014: 21). This explains that the collecting societies basically survived through the direct solar energy collected from the fruits through their collection. While forage societies (huntergatherers), being more complex societies, required both direct solar energy and indirect solar energy, stored in the meat of animals. (Gowdy 1998).

With the arrival of industrial economies, the main energy source ceases to be solar energy (direct and / or indirect), turning fossil natural resources into the primary energy source, this being possible, thanks to the technological improvements that They led to access to fossil fuels through resources such as coal, oil, natural gas, and uranium. Conforming in this way, a substantial change both in the historical energy pattern, and in the economic / political and social model / paradigm, (Hall \& Klitgaard 2018: 7) thus giving birth to a new society such as the industrial one, which quickly passes from having to live With the energy limitations of solar energy, to access all the energy stored on Earth for thousands of years in the form of fossil natural resources. (Van Hauwermeiren 1999: 54). In the following Graphic we can visualize the depth of what this drastic change from an energy point of view has meant for industrial societies and their heirs. In it, the world consumption of primary energy is represented in terawatt hours, differentiating between the different energy sources, on a time scale between the years 1820 and 2015 .

OSORIO-MOLINA, Francisco Manuel. Tourism and energy: classical economics and the oximorum of sustainable tourism. ECORFAN Journal-Mexico. 2020 


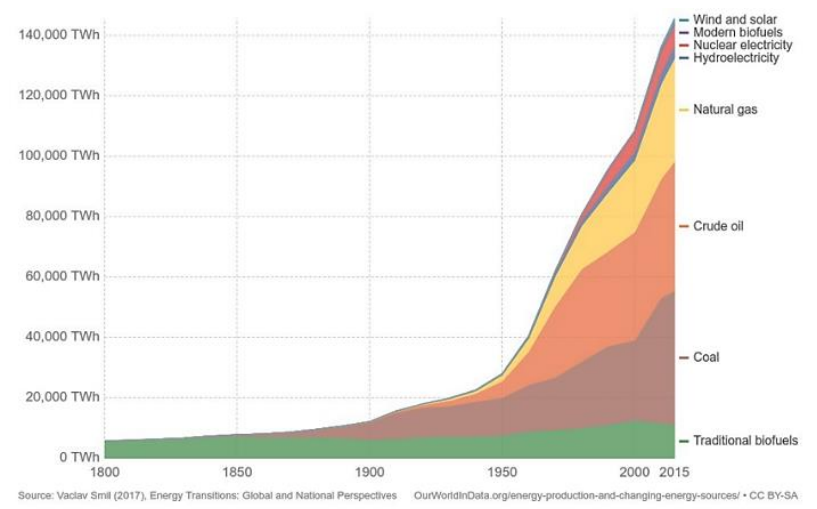

Graphic 1 World consumption of primary energy in Twh, 1800-2015

Source: Vaclav Smil, Energy Transitions: Global and National Perspectives (2017)

This new situation of quasi-unlimited access to energy presents a double problem. Being the most notable, the situation that occurs due to the unrestrained exploitation of the fossil natural resources on which tourism activity in particular (and the economy in general), is totally dependent, exceeding its replacement rate; which is practically nil, since millions of years are needed for the formation of these fuels, as well as very specific and particular geological characteristics. (Hall 2017: 39-42).

When this inevitably happens sooner or later, we will find ourselves at a point where these fossil natural resources are dwindling, causing a decrease in the amount of net energy they can generate to meet the needs of our growing and increasingly complex societies, while at the same time, there is an increase in the cost of extraction, transport, transformation and refining, both energy and economic, of the aforementioned resources. Thus generating a situation, in which increases in the rate of exploitation of these fossil natural resources, cause the decrease in terms of the amount of net energy that these fossil natural resources finally contribute to our societies. (Murphy \& Hall 2011).

Fact, which greatly affects all anthropological activities intensive in energy consumption, such as tourism. Presented this in the end, a clear and evident cost of energy opportunity with other intensive activities in natural energy resources and fundamental for our societies and ways of life, such as those derived from the primary sector, those included in the global agricultural complex and global freight transport.
We are currently immersed in a more than worrying energy situation. The International Energy Agency (IEA) itself, an international body created by the Organization for Economic Cooperation and Development (OECD) after the 1973 oil crisis and whose purpose is to coordinate the energy policies of its member states, with In order to ensure reliable, affordable and clean energy to their respective inhabitants, he accepted this fact outright, recognizing in his 2010 annual report (IEA 2010 ), that the peak of production of conventional oil had already been reached in 2006.

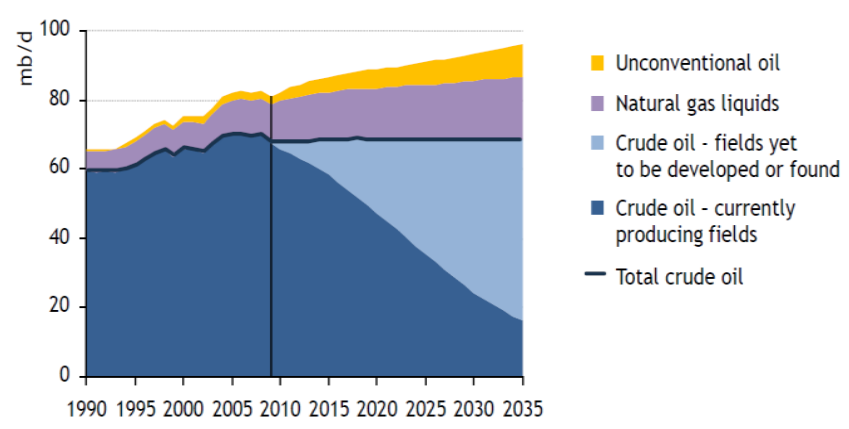

Graphic 2 Prediction of global oil production in the New Policies scenario 1990-2035 (in millions of barrels / day) Source: World Energy Outlook 2010. I.E.A. Figure 3.19

As can be seen in the previous Graphic, the number of barrels of oil that are estimated to contribute to the oil fields currently in operation, (dark blue color), to the global production figure, reached its peak in the year 2006, producing a rapid and constant decline in subsequent years.

Which, surprisingly, would not affect the total production, since this decrease in the production of the current fields, will be compensated by the very optimistic contributions that the IEA presents, from the fields to be discovered (light blue color), together with the new deposits approved and put into operation (gray color). Strategy used on a recurring basis by this international organization.

Already in subsequent years, the following reports from this institution have confirmed the deepening of the energy crisis in which we are immersed. Thus, in the World Energy Outlook of 2016 (IEA, 2016 a), in its figure 3.16, the IEA, taking into account its short-term predictions, shows that there is going to be a significant gap in terms of supply and world energy demand in the time period between the years 2015-2025. 


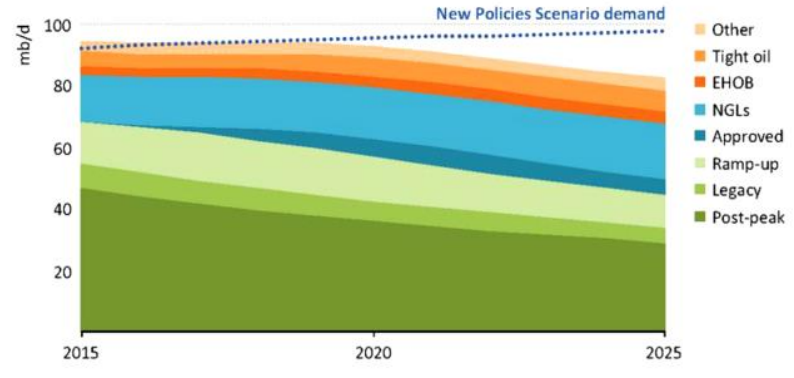

Graphic 3 Forecast and demand of global oil supply differentiating between sources, 2015-2025 (in millions of barrels / day)

Source: World Energy Outlook 2016. I.E.A. Figure 3.16

In 2016, this gap was valued by the IEA at 18 million barrels / day, which meant a difference between demand and global energy production of $18-20 \%$ by the end of 2025. Conjunctural difference, which It would be eliminated according to the IEA's own forecasts, putting into operation in successive years a greater number of deposits found, together with the new deposits put into operation, shown in the following Graphic.

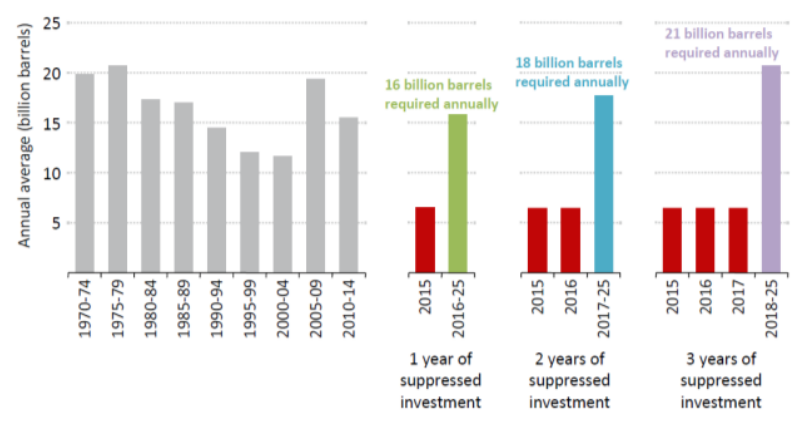

Graphic 4 Total projects to discover and approve fields to cover the gap between supply and demand by 2025 (in billions of barrels / year)

Source: World Energy Outlook 2016. I.E.A. Figure 3.17

But as can be inferred from the previous Graphic, in order for the approved projects for new crude oil fields to close the gap produced between demand and supply in this scenario of new policies, new oilfield projects would have to be approved at constant rates, and historically never seen, except for the punctual period between the years 1975-1979 of overproduction in order to recover production after the second oil crisis; which was a highly improbable circumstance.

To glimpse the level of optimism they had regarding the level of discovery of new deposits, the past predictions of the I.E.A., we will use the chart presented by Holter in his latest study: "Oil discoveries at 70-year low signal supply shortfall ahead.
Bloomberg "The year ahead", in which we can observe the global history of deposits found (in billions / year of barrels) and its future prediction.

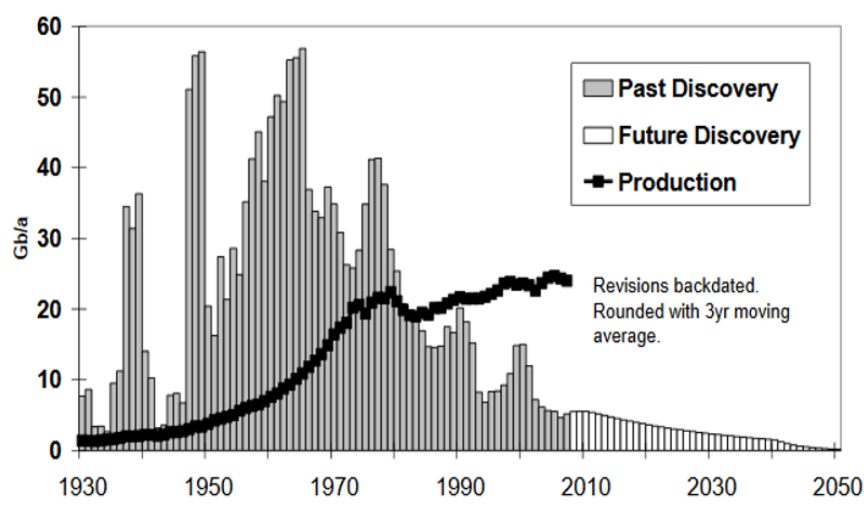

Graphic 5 Global history of crude oil deposits found, future forecast and production level, (in billions of barrels / year) Source: Holter, M., 2016

On the other hand, in November 2018, the IEA published its new annual report (IEA, 2018), where and as expected, we can see that the gap predicted in 2016, far from having been corrected with the new reservoirs found and put into operation, has been increased to a very worrying amount of 34 million barrels / day. Widening the energy gap between demand and supply by $14 \%$ in terms of forecasts made only two years ago in the upcoming 2016. Which practically translates into a very disturbing prediction, which reflects the more than likely decrease of up to $34 \%$ in the supply of oil and its derivatives (including natural gas) global at the end of the year 2025 with respect to the production of the year 2015 .

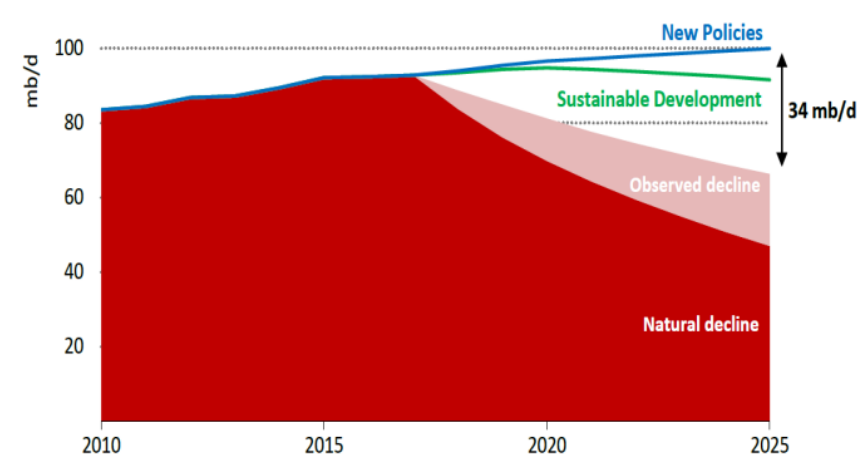

Graphic 6 Prediction of oil production and demand in the New Policies and Sustainable Development scenarios, 20102025 (in millions of barrels of oil / day) Source: World Energy Outlook 2018. I.E.A. Figure 1.19 
This increase in the predicted gap would be justified according to the IEA, due to two factors: the first one, due to the inclusion in its scenarios of a higher percentage that represents the most realistic rate of decline in the exploitation of the current deposits, which today is far from the $3 \%$ per year predicted by the IEA itself, in previous years, to use a much more realistic, although perhaps insufficient, percentage of $5 \%$ per year in its analyzes.

This $5 \%$ seems to be less than the actual percentage of decline, based on the criteria used in the fall of 2016, by the HSBC bank's raw materials section. Whose managers, published a report entitled: "Global oil supply. Will mature field declines drive the next supply cunch?", in which they echoed the undervaluation in the percentage of decline of the current deposits. Report, in which they presented the following Graphic that collects the estimate of global oil production attending to a range of percentages of decline between 5 and $7 \%$ per year, between the years: 2016-2040 in millions of barrels per day.

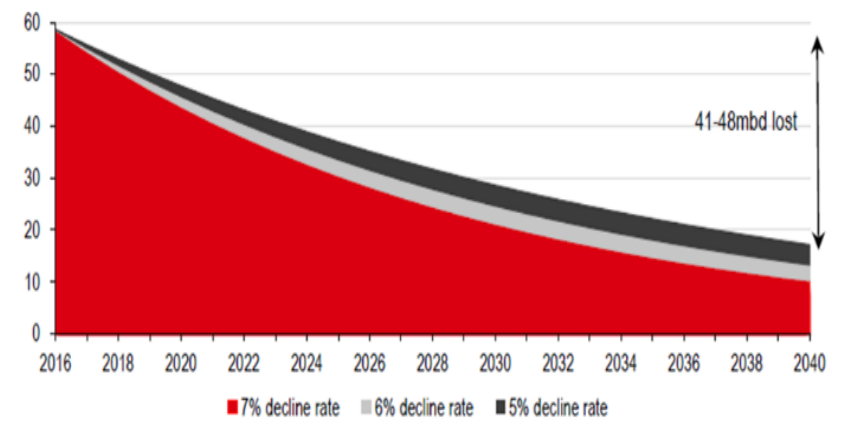

Graphic 7 Prediction of global post peak oil production, taking into account a range of the percentage decline in global production between 5 and $7 \%$ per year Source: HSBC estimates

Secondly, the I.E.A. attributes this increase in the increase in the gap, to the low investments by energy companies, in the search, discovery and exploitation of new deposits. Insistently stressing the need to resume investment rates prior to the collapse of 2008, by energy companies. (I.E.A., 2018: 70-76).

\section{Classical economy and the oxymoron of sustainable tourism}

The second of the problems that occur after the access of industrial societies to fossil natural resources can be found among the current postulates that orthodox economic-political social science defends at the moment.
Since only by validating these, it is possible to construct and normalize concepts made up of antagonistic terms in their biophysical nature, as is the case of the concept: "sustainable tourism".

There are many postulates or assumptions that orthodox political economy elevates to the status of universal laws (Torrez-López, 2016) and that once put under the microscope of the scientific method, they have been discarded, or at least seriously put between said (Urbina 2015). To point out, its founding myths such as: the myth of barter (Humphrey 2007); the myth of "homo economicus" (Graeber 2011); the myth of the self-regulating market (Polanyi 1944), the myth of free trade (Chang 2002) or, at an absolute level, the very validation of economic models that show constant growth over time; the American economist Robert Solow being one of its great pioneers (Solow 1956). These models of unlimited economic growth, which in turn are based on other assumptions such as the following:

Everything that worries human beings has a price and can be bought and sold for money; the value of something is valued at its price; the economy is the original, autonomous and selfregulated open system based on relative scarcity, operating through a conceptual model of the circular flow of exchange value known as "Say's Law" (Say 1803) and the ubiquitous supply and demand diagrams supported by the ceteris paribus and that are shaped, attending to an abstract world where there is perfect competition. That is, a world where there are a plurality of small companies and with such a size that they cannot have the power to set prices in the sector and that, in turn, produce a homogeneous product and therefore qualitatively indifferent. In this idealized world, the model continues, these small companies would have perfect knowledge of the market, the latter translated into perfect information about it, and there would be no barrier to entry or exit from it.

These assumptions result in a model of perfect competition, characterized by efficiency and equity in an economy based on small businesses that are powerless in the face of market designs (Smith 1776), forcing them to compete through price. 
Only by assuming all of the above assumptions can Solow's consistent growth model be accepted. Model, which throughout history has been questioned for being highly impractical by other economists more or less distanced from economic orthodoxy, such as: Joan Robinson (Robinson 1933), Roy Harrod (Harrod 1939), Evsey Domar (Domar 1947) and Edward Chamberlin (Chamberlin 1961) among others. Authors, who in turn have developed models of imperfect competition theory, where companies instead of competing, cooperate for mutual benefit, presenting results characterized by overproduction, excess capacity, and exploitation. Results, which seem more in line with the economic reality that prevails in our societies.

To these criticisms of the perpetual growth model inherited from the classic economic postulates, we must add those pointed out by the pleiad of economic authors included in the areas of bioeconomy and ecological economics. Starting with those whom we can classify as founding fathers of the first: Sergei Podolinsky (Podolinsky 1883), Patrick Gueddes (Gueddes, 1884,) and Frederick Soddy, (Soddy 1922), the only economist to win a Nobel Prize (Nobel Prize of chemistry in 1921, awarded for his contributions to the knowledge of the chemistry of radioactive substances and his research on the origin and nature of isotopes), which have already revealed the deficiencies of the postulates presented by classical economics.

Among all the assumptions that are validated by the orthodox economy, the one that really presents a capital importance to understand why these postulates present a serious problem for the real sustainability of our societies in terms of their way of life, derived from the defense of a primordial and autonomous vision of the economy. From understanding the economy as an open and globalizing system, and therefore, the first study system. Which in the first place, is an unprecedented vision throughout the economic history of humanity, since in all historical times, all societies have presented an economic aspect that has conditioned their lifestyle and development model, but only in the postulates of classical economics do we find the birth and defense of an economy disconnected from ethics and politics, and therefore from society itself (Polanyi, Conrad, Arensberg \& Pearson 1974 pp. 423-424).
And secondly, this implies that for orthodox economists, the nature and biophysical laws of the planet do not represent any limit to economic activity either. One only has to approach classical economic theories regarding Ricardo's comparative advantage (Ricardo 1817) and Smith's theory of absolute advantage (Smith 1776), both precursors of the currently prevailing globalization, to observe that their starting points, In none, is the energy waste that its implementation entails, as well as its environmental cost taken into account. Which ultimately prevents the sustainability of these theories over time, as the fossil natural resources on which they rest, show signs of exhaustion (Jevons 1865).

Ultimately, orthodox economists understand that what they call natural capital (natural resources), and which encompasses nature and its biophysical laws, is substitutable for human capital. This is difficult to sustain, as authors such as Georgescu Roegen (Georgescu-Roegen, 1979, 1986) and Naredo (Naredo-Pérez 2015) have repeatedly pointed out. Since natural capital and capital created by human beings cannot be substitutes as the classical economy postulates, but as it is defended from the bioeconomy and ecological economy, natural capital and capital of human origin, can only be Complementary (Daly 2007, 2012). Since any substitution of natural resources can only be observed by other natural resources with an analogous nature. So these, as well as the biophysical laws that govern them, are clear and forceful limitations to economic activity. (Martínez-Alier and Schlüpmann 1992).

A concept as clear and evident as the previous one, can be visualized, observing what happens if we try to invest the yield (human capital) of overfishing (natural capital) in the construction of more fishing boats (human capital); which does not produce more fish (natural capital). In the same way that the increases in investment that the IEA is urgently requesting, from energy companies, oriented towards technological improvement related to the search, process and exploitation of fossil natural resources, (and which are not occurring), will not they generate new fossil natural resources. Since the improvement in technology is merely limited to presenting an increase in the efficiency of the resource exploitation processes, but in no case can it produce or replace these fossil natural resources (Heinberg 2007). 
However, orthodox economics has based a large part of its postulates on this substitute fiction. Only lasting in time, thanks to the endless exploitation of fossil natural resources that have made possible an unprecedented period of time in terms of obtaining increases in the net energy that our societies have received. But that arrived at the moments of energetic decrease in which we find ourselves, these premises and / or postulates, begin to expose their ineffectiveness, both conceptual and practical. This will force before than after, to rethink the current economicpolitical models, attending to a starting situation, with less availability of net energy, and therefore, the need to include the energy investment that must be carried out to carry out a specific anthropological activity, (and its energy opportunity cost), in addition to the economic and / or environmental costs, in future main economic activities (Klitgaard 2009), as is the case, of the tourist activity.

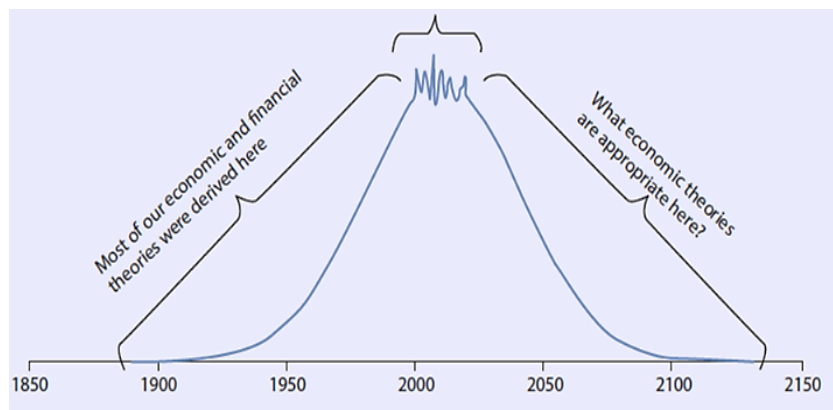

Graphic 8 Relationship of the birth of economic and financial theories that postulate perpetual growth and stagnation and decrease in the production and availability of global fossil natural resources

Source: Hall \& Klitgaard (2018). Energy and the Wealth of Nations, p. 95

\section{Extrapolating the concept of complementarity between natural capital and human capital to the concept of "sustainable tourism"}

The World Tourism Organization (UNWTO) defines sustainable tourism in its glossary of definitions, as follows:

\section{"Tourism that takes full account of current and future economic, social and environmental impacts to meet the needs of visitors, industry, the environment and host communities" $"$.}

This somewhat abstract and generic definition is delimited by the UNWTO when pointing out the essential requirements for the tourist activity to be understood as a sustainable tourist activity, these being the following:

"Sustainable tourism must:

1) Give optimal use to environmental resources, which are a fundamental element of tourism development, maintaining essential ecological processes and helping to conserve natural resources and biological diversity.

2) Respect the socio-cultural authenticity of host communities, preserve their cultural and architectural assets and traditional values, and contribute to intercultural understanding and tolerance.

3) Ensure long-term viable economic activities that provide welldistributed socio-economic benefits to all agents, including stable employment and income-earning opportunities and social services for host communities, and that contribute to poverty reduction".

These three requirements that we can also find in the same glossary, make up what has been understood in the tourist literature as the triangle of sustainability (Pérez-De las Heras) and which encompasses economic sustainability, social sustainability and medium sustainability. environmental (Salinas-Chávez and La O-Osorio).

Presenting these principles, a series of contradictions that are difficult to avoid. The first of them is exemplified in the fact previously exposed, referring to the impossibility of separating the displacement concept from the implementation of tourism activity. Being necessarily, that this displacement is supported by the consumption of fossil natural energy resources. Finite resources, which have an almost zero replacement rate and that although substitutable among themselves, are not human capital resources. Therefore, taking into account the nature of the energy variable, there is no tourist typology that we can classify as sustainable, provided that we understand sustainable as the very concept of sustainability that the Royal Academy of the Spanish Language uses, which includes the precept of temporary endurance.

\footnotetext{
${ }^{1}$ http://sdt.unwto.org/es/content/definicion 
"Sustainable tourism" can only be sustainable if we continue to use the prevailing paradigm for the orthodox economy in which human capital can replace natural capital. And whose one-eyed gaze makes it impossible for us to visualize the true (biophysical) relationships between the economy and natural resources, thus avoiding introducing the limitations that these seconds represent, over the first.

Translating this into unreason, not including the energy variable when analyzing the supposed sustainability that any type of tourist activity may present, even if it is this energy variable, both the prerequisite and the basis of the activity itself.

From this contradiction the oxymoron is born between the terms tourism and sustainable. Since the dominant paradigm presents "sustainable tourism" activity, as an activity that can not only be maintained ad eternun, but also has the capacity to increase exponentially each year. Which, taking into account the biophysical limitations previously indicated, is still a hardly defensible contradiction.

Contradiction, which is much more notable, if it is taken into account the fact that the consumption of fossil natural resources as a prerequisite for the "sustainable tourist activity" to occur, is already something contrary to the first requirement necessary for the activity to occur "Sustainable tourism" according to UNWTO. All this, without stopping to attend to the environmental problems inherently associated with the use (burning) of natural fossil fuels, which aggravate the most pressing environmental problems today, (Torres: 2020) such as global warming, climate change, loss of global biodiversity or human deaths associated with air pollution, which the IEA itself already quantified at 6.5 million / year in its 2016 special report, (IEA 2016 b). Or to the fact of having reduced the tourist activity, to a mere payment for the use of the territory and its resources, renouncing that it acts as a forum to exchange ideas, and as a vector of social change (Fernández-Arroyo: 2020).

\section{Conclusions}

Currently, our societies receive $89.59 \%$ of the primary energy we consume, from four fossil natural resources such as oil, natural gas, coal, and uranium (BP Stadistics 2018), which have a finite nature, not Renewable and not substitutable by human capital, and which are currently presenting unequivocally strong and tangible samples of a rapid and extremely worrying decline in both their availability for exploitation and their energy quality. (Gagnon, Hall \& Brinker 2009).

This, in turn, generates the energy opportunity cost between the tourist activity and the rest of the anthropological activities intensive in the consumption of fossil energy resources, which are so necessary for the maintenance of our current societies and ways of life (Hall, Lambert, Balogh . 2014), such as mining, global freight transport, maintenance of structures related to ICTs or the global agricultural system, is greater as fossil energy natural resources continue to decline.

Fact, which inevitably from the academic and professional world, we will have to attend to, and which ultimately requires the necessary inclusion of the energy vision as one more edge in that pleiad of different views that make up the current quasi-systemic vision with which we are approaching the study of tourist activity. In order to be able to analyze, study and understand the problems that tourism activity presents, from now on, a true totalizing systemic perspective. Even though this supposes us to question the objectionable postulates of classical economic social science, which make up the current economic, political and social paradigm.

\section{References}

BP (2018): "Statistical Review of World Energy". Disponible en:

https://www.bp.com/en/global/corporate/energyeconomics/statistical-review-of-world-energy.html

BAUMAN, Z. (2016): "Modernidad líquida", Madrid, Fondo de cultura económica de España.

BENDODO-BENASAYAG, E., FERNÁNDEZ GÁMEZ, M. A. y SÁNCHEZ SERRANO, J.R.: Un análisis de la eficiencia de los municipios turísticos españoles. Cuadernos de turismo, no 43 (2019), pp. 147-168. 
BIZBERG, I., MORAYTA, G. C., \& MABIRE, B. (2020). El fracaso de la continuidad. La economía política del sexenio de Enrique Peña Nieto. Foro Internacional, 60(2 (240), 629-682.

CABRERIZO-SAINZ, C. (2016): "La ciudad del negocio: Turismo y movilización social en pugna", Madrid, Cisma.

CHAMBERLIN, E. H. (1961): "The Origin and Early Development of Monopolistic Competition Theory", Quarterly Journal of Economics, Vol. 75, pp. 515-543.

CHANG, H., J. (2002): Kicking Away the Ladder: Development Strategy in Historical Perspective. London, Anthem Press.

DALY, H., E. (2007): Ecological Economics and Sustainable Development. Northampton, University of Maryland Press.

DALY, H. E., FARLEY, J., COSTANZA, R. et all., (2012): Building a Sustainable and Desirable Economy in Society in Nature. New York, United Nations. Division for Sustainable Development.

DANTE-URBINA, A. (2015): Economía para herejes. Desnudando los Mitos de la Economía Ortodoxa. Lima, Amazon Edition.

DELGADO, M., REIGADA, A., SOLER, M. y PÉREZ-NERIA, D.: Medio rural y globalización. Plataformas agroexportadoras de frutas y hortalizas: los campos de Almería. Papeles de relaciones ecosociales y cambio global, $\mathrm{n}^{\circ} 131$, (2015), pp. 35-48.

DOMAR, E. (1947): "Expansion and employment". American Economic Review. 37 (1): 34-55.

\section{FERNÁNDEZ-ARROYO}

LÓPEZ-

MANZANARES, A. (2020). Geografía social del turismo. Una mirada crítica a la percepción del turismo ya su representación espacial. Cuadernos de Turismo, 45, (2020), 113-119.

FERNÁNDEZ-DURAN， R. y GONZÁLEZREVES, L. (2014): La espiral de la energía volumen I: Historia de la humanidad desde el papel de la energía, Madrid, Libros en Acción, pp. 21.
GAGNON, N., HALL, C. \& BRINKER, L. (2009): "A preliminary investigation of the energy return on energy investiment for global oil and gas production", Energies, Vol. 2, pp. 490-503.

GEORGESCU-ROEGEN, N. (1979): "Energy Analysis and Economic Valuation", Southern Economic Journal, Vol. 45, no 4, pp. 1023-58.

GEORGESCU-ROEGEN, N. (1986): "The Entropy Law and the Economic Process in Retrospect', Eastern Economic Journal, Vol. 12, ${ }^{\circ}$ 1, pp. 3-25.

GOWDY, J. (1998): Limited wants, unlimited means, Washington DC, Island Press.

GRAEBER, D. (2012): Debt, the first 5.000 years. New York, Mellville House.

GUEDDES, P. (1884): John Rusking. Londres, W. Bronm.

HALL, A.S.C., LAMBERT, J. G. \& Balogh, S. (2014): "EROI of different fuels and the implications for society" Energy Policy, Vol. 64, pp. 141-152.

HALL, A.S.C. (2017): Energy Return on Investment: A Unifying Principle for Biology, Economics, and Sustainability, Syracuse, New York, Springer, pp. 39-42.

HALL, A.S.C. \& KLITGAARD, K. (2018): Energy and the Wealth of Nations: An Introduction to Biophysical Economics, Second Edition, New York, Springer, pp. 7.

HARROD, R. (1939): "An essay in dynamic theory”. Economic Journal, 49 (1), pp. 14-33.

HEINBERG, R. (2003): The party's over. Canada, New Society Publishers, Gabroiola Island.

HOLTER, M. (2016): “Oil discoveries at 70-year low signal supply shortfall ahead. Bloomberg, [on line], fecha de consulta: enero 2019, disponible en: https://www.bloomberg.com/news/articles/201608-29/oil-discoveries-at-a-70-year-low-signal-asupply-shortfall-ahead

HSBC (2016): "Global oil supply. Will mature field declines drive the next supply cunch?", [on line], fecha de consulta: enero 2019, disponible en: https://www.ourenergypolicy.org/global-oilsupply-will-mature-field-declines-drive-the-nextsupply-crunch/

OSORIO-MOLINA, Francisco Manuel. Tourism and energy: classical economics and the oximorum of sustainable tourism. ECORFAN Journal-Mexico. 2020 
HUMPHREY, C. (2007): Trueque, intercambio y valor: un acercamiento antropológico. México, Abya-yala.

IEA (2010): “World Energy Outlook”, Agencia Internacional de la Energía, París, pp. 122.

IEA (2016 a): “World Energy Outlook”, Agencia Internacional de la Energía, París.

IEA (2016 b): "World Energy Outlook Special Report", [on line], fecha de consulta: febrero 2019, Disponible en: https://www.iea.org/publications/freepublication s/publication/WorldEnergyOutlookSpecialRepor t2016EnergyandAirPollution.pdf

IEA (2018): “World Energy Outlook”, Agencia Internacional de la Energía, París.

JAFARI, J. (2005): "El turismo como disciplina científica", Política y Sociedad, vol. 42, no 1, pp. 39-56.

JEVONS, W.S. (1865): The coal question: An inquiry concerning the progress of the nation and the probable exhaustion of our coal mines. London and Cambridge, MacMillan and Company.

KLITGAARD, K. (2009): "Time for a change in economic theory". Proceedings of the 61st Annual Convention of the New York State Economics Association I, pp. 54-63.

LAMBERT, J.G., HALL, C.A.S., BALOGH, S., GUPTA, A. \& ARNOLD, M. (2014). "Energy, EROI and quality of life", Energy Policy n ${ }^{\circ} 64$, Elsevier, pp. 153-167.

LÓPEZ-BONILLA, J.M.; GRANADOSPEREA, C. y LÓPEZ-BONILLA, L. M. (2018): "Producción científica española en turismo: un análisis de autoría basado en revistas internacionales con alto impacto y visibilidad", Cuadernos de Turismo, vol. 41, pp. 343-367.

LÓPEZ-GONZÁLEZ, José Luis; MEDINAVICENT, Maria (2020). «Las Kellys y el turismo: de la invisibilidad del cuidado a la visibilidad política». [artículo en línea]. Digithum, n. ${ }^{\circ} 25, \mathrm{pp}$. 1-13. Universitat Oberta de Catalunya y Universidad de Antioquia. [Fecha de consulta: dd/mm/aa]. http://doi.org/10.7238/d.v0i25.3175
MARTÍNEZ-ALIER，J. y SCHLÜPMANN，K. (1992): La Ecología y la economía. Madrid, Textos de Economía: Fondo de Cultura Económica.

MOREL-MONZÓ, S y MEMBRADO-TENA, J.C. (2018): "Causas y consecuencias del crecimiento urbanístico en el litoral valenciano a través de los usos del suelo. El caso de Oliva. Cuadernos de Turismo, no 44, (2019) pp. 303-326.

MÜLLER, E. A. (2002): Termodinámica básica, Sevilla, Publidisa, pp. 165 y 181.

CARDONA, Á. M., \& SOTO, L. M. (2020). Emprendimiento social y felicidad urbana. SUMMA. Revista disciplinaria en ciencias económicas y sociales, 2(1), 127-169.

MURPHY, J., D. \& HALL, A.S.C. (2011): “Energy return on investment, peak oil, and the end of economic growth", Ecological Economics Reviews, New York, n 1219, pp. 52-72.

NAREDO-PÉREZ, J., M. (2015): La Economía en Evolución, $5^{\circ}$ Edición. Madrid, Editores Siglo XXI. OMT (2011): "Tourism Towards 2030: Global Overview”, Organización Mundial del Turismo, Madrid, pp. 15.

OMT (2016): "Panorama del turismo internacional”, Organización Mundial del Turismo, Madrid, pp.2.

OMT (2019): "Travel \& Tourism Economic Impact”, Organización Mundial del Turismo, Madrid, pp. 1 y 7.

PÉREZ-DE LAS HERAS, M. (2004): Manual de turismo sostenible. Madrid, Paraninfo.

PODOLINSKY, S. (1883): "Menschliche Arbeit und Einheit der Kraft", Die Neue Zeit, Vol 1, n 9, pp. 413-24 and, no 10, pp. 449-57.

POLANYI, K. (1944): The Great Transformation: The Political and Economic Origins of Our Time in The Early Empires. New York, The Free Press.

POLANYI, K., CONRAD, M., ARENSBERG, H. \& PEARSON, W. (1974): Trade and Market in The Early Empires. New York, The Free Press.

PRIETO, P. \& HALL, A.S., (2012): "Spain's Photovoltaic Revolution: The energy return on investment", Springer, New York. 
RICARDO, D. (1817): On the Principles of Political Economy and Taxation. London, John Murray, Albemarle Street.

ROBINSON, J. (1933): The Economics of Imperfect Competition. London, Macmillan.

SALINAS-CHÁVEZ, E. y LA O-OSORIO, J., A. (2006): "Turismo y sustentabilidad", Cuadernos de Turismo, $\mathrm{n}^{\circ}$ 17, pp. 201-221.

SAY J., B. (1803) : Traité d'économie politique, Traité d'économie politique ou simple exposition de la manière dont se forment, se distribuent et se composent les richesses. París, Crapelet.

SMITH, A. (1776): An inquiry into the nature and causes of the wealth of nations. Londres, Willian Strahan \& Thomas Cadell.

SODDY, F. (1922): Cartesian Economics: The Bearing of Physical Science upon State Stewardship. London, Hendersons.

SOLOW, R. (1956): "A contribution to the theory of economic growth", Quarterly Journal of Economics, vol. 70, n 1, pp. 65-94.

TORRES, J. F. (2020). Política ambiental y desarrollo sustentable: Un enfoque latinoamericano. Eduvim.

TORREZ-LOPEZ. J. (2016): Economía para no dejarse engañar por los economistas. Madrid, Deusto Ediciones.

VAN HAUWERMEIREN, S. (1999): Manual de Economía Ecológica, Quito, Instituto De Estudios Ecologistas del Tercer Mundo, ILDIS, pp. 51 y 54. 